\title{
Buddhism in the Orenburg Cossack Troops in the Period between Two Russian Revolutions (the Beginning of the XXth Century)
}

\author{
Sergey Lyubichankovskiy ${ }^{1}$ \\ ${ }^{1}$ Orenburg State Pedagogical University
}

\begin{abstract}
The article studies the problems of the confessional organization of the Cossacks-Kalmycks of Orenburg Cossack Troops, who achieved the permission to transfer from the Orthodoxy into Buddhism (Lamaism). The lack of leading directions of the Government and pressure of the Diocesan Committee of the Orthodox Missionary Society made it difficult to grant the legal status of religious organization to the Buddhist communities. That is why Orenburg Buddhists were limited in their civil rights and religious needs
\end{abstract}

Keywords: Buddhism (Lamaism), the Kalmyks, the Cossacks, Orenburg Cossack Troops, denomination, missionary

\section{Introduction}

In Orenburg troop, Followers of Tibetan Buddhism (Lamaism) were a small group of Cossacks-Kalmyks , who have fallen away from the Orthodoxy after the publication of decree of the religious toleration in $17^{\text {th }}$ of April, in 1905. According to information of the Orenburg Diocesan Committee, by 1915 from 978 Cossacks of Kalmyk origin 254 persons became Buddhists and 211 persons were reckoned to hesitant, because they didn't have a permission to change peligion. Recently, problems of religious organization and religious life of Orenburg Buddhists came into the view of historians [1, 2, 3, 4].

Orenburg Kalmycks in keeping of their religion almost never went beyond of the legal framework. An observance of Christian ceremonies and reverence to the parish clergy cleared suspicion of their unreliability. In 1906, a year after the publication of the Decree about strengthening tolerance, Kalmyks began to file petitions for a change of religion. The first Buddhist community was registered on the territory of the troops in the village Varshavsky in 1906. In 1915, there were 30 people - 13 men and 17 women. Next community in the village Tolstinsky appeared just in five years in 1911.

\section{Bureaucratic Process of Transition of Christianity to the Buddhism}

Between the filing petitions and the official recognition of the right to Kalmyks practice of religion of their ancestors were the years of uncompromising struggle against bureaucratic hurdles. In particular, papers of a case «About Cossack's conversion of Ismailsky village of Kizilskaya stanitsa in Dalai Lama faith» testify to this. The petition, signed by fifteen Cossack-Kalmyks, was presented to the Military economical administration of Orenburg Cossack army in late 1906. The petitioners proved that they, like their ancestors, despite the adoption of Orthodox Christianity, in 1737 had always remained committed to Lamaism, and the Christian faith preached by Orthodox priests «to the conscience did not accept». Kalmyks tried to present Nicholas II as a guarantor of freedom to worship and as their imperial patron.

They expressed confidence that «the fundamental laws of the Empire commands that orthodox and heterodox sbjects of His Majesty quite freely and zealously professed their religion. Thus, our position in relation to religion should be considered fully secure and does not allow any uncertainties». The Kalmyks, who signed the petition, asked the ataman exclude them and their families from the Orthodox metric lists, as well as in the future, local officials and Orthodox clergy treated them not as a fallen away from the Orthodox Church, 
but as a fundamentally «the Dalai Lamaists» and not interfere in their religious affairs. All this was summarized rhetorical proposal to free the sake of fairness, humanity and religious freedom from all oppression and persecution. On this occasion of the petition ispravnik of the uyezd made a police inquiry. Naturally, the police became interested in the attitude of the Kalmyks to Orthodoxy before the adoption of the decree on religious tolerance. A report presented by parish Obruchevskiy testified that in earlier times the Kalmyks shied away from confession and Holy Communion. Though the rest of the rites of Orthodox Church they perform, but they did it reluctantly and under the threat of punishment. A consideration of Kalmyk's petition of Ismail village took five and a half years. The Orenburg Provincial Government has taken a positive decision on the Kalmyk's petition on $12^{\text {th }}$ May, 1912. By this time, two of the fifteen signatories of Kalmyk's petition died and one of them has refused to change a religion [5].

By the middle of the second decade of XX century, the fourth part of the Kalmyk population in Orenburg made use of the right to change a religion. They formed communities in four villages: Varshavsky, Izmailsky, Kulevchinsky, Tolstinsky.

\section{Fight of Cossacks for the Status of Buddhist Communities}

The subsequent actions of Orenburg Kalmyks-Lamaists were aimed at recognition of the status of parish to their communities and granting the right to register acts of civil status, the right to build temples, to gather to worship openly and freely. Thus, on $28^{\text {th }}$ December in 1914 the Kalmyks, the residents of the village Kulevchinskiy of stanitsa Nikolaevskaya made a public document in which they asked to commission formally in the capacity of clergyman Cossack Philip Fedorov Baraslan, who served gelyung. Orenburg Kalmyks had resource for assistance to in resolving organizational issues to spiritual leaders of Kalmyk Buddhists -to Baksha of Don Kalmyks and to Supreme Lama of the Kalmyk people.

Essentially a staff report wrote by Baksha of Don Kalmyks Menke Bakarovich Bormanzhinov on $9^{\text {th }}$ September, in 1910 marked the beginning of the correspondence «The Structure of the Spiritual Administration of the Buddhists of the Ural and Orenburg Cossack troops». Bormanzhinov focused an attention on the absence of a spiritual administration regulated by law for local Kalmyks. The lack of spiritual administration he realized as inconstancy of the staff clergy and of approval process of the clergy in spiritual ranks. In the case of an uncontrolled increase in the number of persons dedicated to the clergy, their keeping became burdensome for the Kalmyks. Because of the paucity of Orenburg Kalmyks Baksha have decided to establish for them a house of prayer, but not a special khurul (monastery). The appointment of clergy was determined by the high priest of the department to which will be attached Orenburg Buddhists.

M.N. Bormanzhinov asked to convey the Orenburg and Ural Buddhists under his spiritual care because they "are in exactly the same conditions of life, civilian and military responsibilities and social order with the Don Kalmyks». The Baksha of Don Kalmyks undertook to regulate the ordainment in dignity of mandzhik, getsul and gelyung and include them into the staff defined by the law and monitor their activities. $7^{\text {th }}$ November, 1913 Chimid Baldanov - Lama of the Kalmyk people asked for explanations from the ataman of the Orenburg troops on the sitatus of the local Kalmyks and their subjection of spiritual issues [6].

The provincial administration has been very interested in the settlement of the legal status of the Orenburg Buddhists. Because this issue was not included in its competence, Orenburg governor asked for instructions to the Department of Religious Affairs of Foreign Confessions of the Ministry of Interior. On this subject, $6^{\text {th }}$ November, 1911 Governor N.A. Sukhomlinov sent a request, in which he asked for clarifications on the question of laying on of management of Lamaist spiritual issues on provincial authorities. He was interested in the requirements for the construction of religious buildings, appointment to the staff positions of officers and the existing hierarchy between them, raised the question of the teaching of the Buddhist doctrine in school. In conclusion, N. A. Sukhomlinov recommended that the Department designate a competent person to translate religious texts and preparation on their basis of a brief guide, "because without the necessary knowledge, the age-old struggle of the church against ignorant religion will continue fruitless, as it has been for 300 years". 
Orenburg governors another three times - March 13, 1913, February 2, 1915 and September 16, 1916 - asked for orders to the Department of Religious Affairs. They received a reply only once. June 19, 1913 Deputy Director of the Department informed the N.A. Suhomlinov that «the question of the settlement of the spiritual life of Orenburg Lamaists is currently in the process of necessary interagency relations and corresponding instructions cannot yet be reported to Your Excellency» [6]. Apparently, such a situation without taking any legislation, lasted until the February Revolution of 1917.

Delaying a formal decision on including "waverers" Kalmyks to Buddhism-Lamaism led to the fact that they no longer wait for any permission. As a result, like the Buddhists, the Kalmyks who remained formally Orthodox ignored the Christian rites. The dead were buried without a priest, young people get married without the consent of the elders, the baptism of children and metric acts become optional.

\section{Position of Russian Orthodox Church}

Legalization of Tibetan Buddhism, has revealed the incompatibility of the interests of the state and the Russian Orthodox Church, represented in this case, the Orenburg diocese. The state allowed Orenburg Kalmyks to change religion, and it was forced to look for ways to ordering of their religious life, to give it legitimacy, and to control the activities Lamaist clergy. Russian Orthodox Church saw in government measures threat of definitive loss of the spiritual influence on the Kalmyk population and total falling away of Kalmyks from Orthodoxy.

Aleksei Matveevich Pozdneev, a member of the Minister of Education, a prominent Russian orientalist, Professor, most consistently expressed the interests of the state in "Buddhist issue." In 1911 he was made an expedition to the Terek, Ural and Orenburg Kalmyks. He visited several villages of the Orenburg Cossack army, spoke to representatives of the Kalmyk clergy and ordinary Kalmyks, heard a lot of complaints about the oppressions and requests for assistance. Analyzing the causes of Kalmyks mass defection from Orthodoxy A.M. Pozdneev emphasized the inability of Orenburg Orthodox clergy to oppose this process. At the same time, he found a lot of discrepancies in the views of the Kalmyk clergy rites and dogmata in Lamaist doctrine with respect to the actual content of this religion.

Pozdneev convinced that the initiative of a return to the ancestral religion was "purely local - and had the same historical and social bases." He offered to put on the Kalmyks-Lamaists high priest or lama who will be loyal to the authorities. His duties, apart from the initiations to spiritual and issuing appropriate literacy should include "surveillance of Orenburg Lamaist clergy" [7]. A.M. Pozdneev advised to entrust the affairs of Orenburg Kalmyks-Lamaists to Baksha (lama-teacher) of Don Kalmyks Bormandzhinov, who was a law-abiding and had a knowledge of Lamaist doctrine.

Kalmyks, who expressed their full alienation from Lamaism and devotion to Orthodoxy, should be entrusted to the care of Christian pastors. Pozdneev believed that maintaining the Orenburg Kalmyks in the bosom of the Christian Church depends on the organization and the level of training of Orthodox missionaries.They should have a good understanding of the tenets of Buddhism-Lamaism, saying in the Kalmyk language, know the customs and traditions of the Kalmyk people [7].

In 1911, the Orenburg diocesan committee of the Orthodox Missionary Society was forced to admit the presence of religious separatism among Orenburg Kalmyks. For the first time in an official document of the Orenburg diocese, paid attention to such negative phenomena as formal attitude of the baptized Kalmyks to the Orthodox rite, the rejection of fasting, evasion from visits to a church service and so forth.

Diocesan Committee had hoped to restore former positions and get the Kalmyk-apostates to Christianity by the appointment of a special missionary. The most appropriate person for missionary activity among the Kalmyks was a "cenobite-hieromonk, free from the bonds of family and does not require too large material costs" [7]. In accordance with the initiative put forward by the Diocesan Committee within the limits of Troitsky, and Verkhneuralsky and Orskiy uyezds separate anti-Lamaist Missionary District was formed. It includes 21 of the Cossack villages that included a Kalmyk population. September 23, 1914 John Kharitonov was appointed a 
district missionary, who was transferred from the Transbaikalian diocese and at the same time was a priest of Kazan-Bogorodicheskoy church in Kulevchinsky village. By this time the Cossacks-Kalmyks 120 - 62 men and 58 women in the village Kulevchinsky changed the religion [8]. Ivan Kharitonov was in the position of the district missionary for two years. September 27, 1916 he was appointed regimental priest in the 163rd Infantry Reserve Regiment, stationed in Chelyabinsk.

A comparison A.M. Pozdneev 's report with the reports of district missionary shows a remarkable polemic between the official-intellectual, expressed the interests of the state with the professional Orthodox missionary zealously defended the interests of the Russian Orthodox Church. Kharitonov's views on the root cause of a mass defection from Orthodoxy Kalmyks were diametrically different from the conclusion of Pozdneev. From communicating with Kalmyks Orthodox missionary drew the conclusion that encourage them to change their religion could only external influence. Frequent visits of Buddhist preachers from Transbaikalia to Orenburg Kalmyks caused particular concern of Father John. According to Kharitonov, coming Lama inspired Kalmyks, that "every nation has its own character and each nation should strive for independent creative life. The path to the cultural life must flow without pressure from someone else hand. Therefore, the care of the inorodtsy (it is a legal term used in the Russian Empire; meaning "of different nation") as the spiritual and civil authorities was interpreted by progressists as an invasion of their original life. In their opinion, it paralyzed the creative activity of the their population" [5].

Ivan Kharitonov bracketed professor Pozdneev in one row with visiting preachers Lamaism and most as mass defection from Orthodoxy to Lamaism occurred precisely in those villages he visited. Ivan Kharitonov likened professor A.M. Pozdneev with lamaists-preachers, because a massive falling away from Orthodoxy to Lamaism occurred precisely in those villages he visited. According to information collected by a missionary, Pozdneev explained the essence of the Buddhist doctrine, spoke about the rituals performed Lamaists. In the future, he promised to continue consulting Orenburg Lamaists on religious worship, send plan of a joss-house khurul and support the application for its construction. BaksaYegor Tumatov, inspired by promises of Pozdneev, who headed Lamaists of Ismail village community, began to collect donations for the construction of the josshouse and to persuade Orthodox Christians Kalmyks to change the religion [4].

Also I. Kharitonov refers to the negative external factors impacted on the worldview of the Kalmyks moral and religious licentiousness of some representatives of the Russian population. He believed that the Russians passionate about liberation movement, deny the existence of God and the "ridicule everything that is holy and dear to every Orthodox Christian" [5]. Father John believed the local Buddhist clergy and their followers were his main opponents in the fight for «the erring souls of the Kalmyks». In a missionary report for 1915, he pointed out that the former Assistant of the Ataman Mikhail Boroslan in village Nikolaevsky, his brother Philip Boroslan and Cossacks: Yakov Kubiyun from Kulevchinsky village, Ivan Bosanov from Leipzigsky village, Cornelius Zhemchuev from Tolstinsksy village, Gerasim Isheev from Verinsky village, Athanasius Boshaidykov from Varshavsky village, self-styled "Baksha" from Izmailsky village Yegor Tumatov popularized "idolatrous" religion.

District missionary believed that anti-Orthodox movement was raised by them just out of ambitions, and "no other reasons, because all of the local Kalmyks do not understand the Buddha-Lamaism." He reported to the Diocesan Committee that gelyung Kubiyun encourages Kalmyks "in buddo-lamaizm, and affects on the psyche of the local Kalmyks, bypassing the law. And we need to take administrative measures to Kubiyun» [8].

Kharitonov admitted that Orenburg Kalmyks had the Lamaist organization headed by gelyungs since ancient times. Already then the Kalmyks, who were weak in Orthodoxy" secretly performed the rites of Lamaist idolatry." But in those times, according to Kharitonov, apostates were few. after the promulgation of the decree on religious tolerance, "idolatry, and the transition from orthodoxy became permissible and explicit." Lamaists united in religious communities, and through them to exert a strong influence on the Orthodox Kalmyks.

According to the father of John, they yielded to the propaganda of those communities. In addition, the Russian Orthodox population did not exert moral support to Kalmyks and treat them with neglect, considered 
them not fussy about food and uncleanly. Ivan Kharitonov and the Diocesan Committee, tried to present the spread of Lamaist movement among Orenburg Kalmyks not so much a religious movement, but as political, which is caused by external causes. But we know that every political movement which is not sanctioned by the government, was seen as anti-state, undermines the foundations of the existing system in the Russian Empire. But its known that every political movement, which is not sanctioned by the government, is considered as antistate, and it undermines the foundations of the existing system in the Russian Empire. Therefore, if the government will support the Orenburg missionaries and forbid Lamaist preachers to visit freely local Kalmyks, the apostate movement "will not have further progress, and apostate Kalmyks will return to the bosom of the Orthodox Church" [5]. Father John had not been able to openly criticize the Decree on the religious tolerance as the will of the supreme authority, but he paid attention to numerous violations of its most important postulate the principle of voluntariness.

Drawing on the example of the petition for permission to change religion, made up by Cossack-Kalmyks from Kulevchinsky village, Kharitonov proved that such petitions on behalf of the Kalmyks, who lived in the village, including orphans, children and adults, who did not want to leave Orthodoxy, approved by the Consistory without any administrative check.

\section{Conclusion}

Diocesan and Cossack authorities could not prohibit the Kalmyks use legitimate right to change religion. However, the pressure exerted by the district missionary and the absence of guidance from the government made the difficulties for the decision to recognize the Kalmyks Buddhists and for giving to Buddhist communities the legal status of religious organizations.

As a result, Orenburg Kalmyks were in a legal vacuum. They no longer had to hide their true religion. They were able to communicate with their co-religionists and even established contacts with spiritual leaders of Russian Buddhists. But they were the Cossacks of Orenburg Cossack troops and resident in its territory, and had limitations in exercising their civil rights and religious needs. The first limitation relates to the registration acts of civil status, the second was linked with the ability to worship according to the canons of Buddhism (Lamaism). The Temporary Government was working on a law about device of the spiritual life of the Buddhists at a national level. After its adoption, the legal certainty would be spread to Orenburg Buddhists. However, after the establishment of Soviet power law guaranteeing the right to religious freedom could not be accepted.

\section{References}

[1] S.V. Dzhundzhuzov, "Konfessional'naia organizatsiia orenburgskikh kalmykov lamaistov v nachale XX veka", Evraziiskoe ozherel'e, vol. 4, pp.99-124, December 2004 [in Russian].

[2] S.V. Lyubichankovskiy, "Russia's Regional Governance at the Change of Epochs: Administrative Reform Drafts in the Late 19th-Early 20th Centuries", Bylye Gody, vol. 36, is. 2, pp.309-318, June 2015.

[3] S.V. Lyubichankovskiy, "Local Administration in the Reform Era and After: Mechanisms of Authority and their Efficacy in Russia”, Kritika: Explorations in Russian and Eurasian History, vol.13, № 4, pp. 861-875, Fall 2012.

[4] E.M. Esikova, "Missionerskaia deiatel'nost' Russkoi pravoslavnoi tserkvi sredi kalmykov Orenburgskoi eparkhii (1859-1917 gody)”, Vestnik Cheliabinskogo universiteta, vol.34, №28, pp. 134-141, September 2009 [in Russian].

[5] State Archive of the Orenburg Region, fond 175, opis 1, delo 171.

[6] State Archive of the Orenburg Region, fond 175, opis 1, delo 1102.

[7] Archive of Orientalists of Institute of East Manuscripts of the Russian Academy of Sciences, fond 44, opis 1, delo 60.

[8] Otchet o deiatel'nosti Orenburgskogo eparkhial'nogo komiteta Pravoslavnogo missionerskogo obshchestva za 1914 god. Orenburg region press, Orenburg, 1915, pp.7-398 [in Russian]. 